\section{Reactions of an Iminophosphoranylidene Carbenoid **}

Wolfgang Schilbach, Volker von der Gönna, Dietrich Gudat, Martin Nieger, and Edgar Niecke*

Vinylidene carbenoids $\mathbf{I}$ are of major significance as synthetic building blocks in organoelement chemistry. ${ }^{[1]}$ However, little is known about this type of carbenoids with phosphorus as heteroatom (II-IV). Only for the phosphanylidene carbenoid system II have several experimental investigations been made. ${ }^{[2]}$ Here we report on the synthesis and reactivity of an iminophosphoranylidene carbenoid of type IV, in which the phosphorus atom is in a trigonal-planar coordination environment.<smiles>[X]C(C)=C(C)C</smiles>

I<smiles>[X]C(Cl)=PC</smiles>

II<smiles>[X]C([CH])=P(C)(C)C</smiles>

III<smiles>[X]C([AlH2])=P(=C)C</smiles>

IV
Bis(aryl)iminophosphane ${ }^{[3]}(\mathbf{1})$ reacts easily with trichloromethyllithium to give imino(dichloromethylene)phosphorane (2); subsequent reaction with $n$-butyllithium in THF at $-105^{\circ} \mathrm{C}$ results in a deepening of the color of the solution, suggestive of the formation of a carbenoid 3 as an intermediate $\left({ }^{31} \mathrm{P}\right.$ NMR: $\delta=83.2 ; J_{\mathrm{PLi}}=25 \mathrm{~Hz}$ ). This intermediate can be trapped as the<smiles></smiles><smiles>CC(C)(C)[GeH3]</smiles><smiles>[R]P(=[Cr])=[W]</smiles>

2
$\left(\mathrm{R}=2,4,6-t \mathrm{Bu}_{3} \mathrm{C}_{6} \mathrm{H}_{2}\right)$

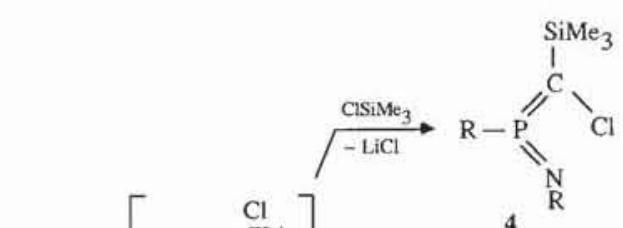

4

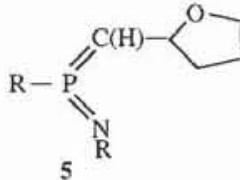

[1] Prof. Dr. E. Niecke, Dr. W. Schilbach, Dr. V. von der Gönna, Dr. D. Gudat. Dr. M. Nieger

Anorganisch-chemisches Institut der Universität

Gerhard-Domagk Strasse 1. D-53121 Bonn (FRG)

Telefax: Int. code $+(228) 735327$

[**] This work was supported by the Deutsche Forschungsgemeinschaft and the Fonds der Chemischen Industrie. thermally stable, C-silylated substitution product 4 by the subsequent addition of chlorotrimethylsilane. In the absence of an electrophile, 3 reacts with the solvent to give the imino(tetrahydrofuran-2-yl-methylene)phosphorane 5 , which can formally be regarded as an insertion product of an iminophosphorylidene carbene with tetrahydrofuran. Reaction of intermediate $\mathbf{3}$ and triphenylphosphane yields the "phosphane-adduct" phosphonio(iminophosphoranylidenemethanide) (6a) as a stable final product. The compound $\mathbf{6 b}$ obtainable by the corresponding route with trimethylphosphane is, however, not stable in solution but isomerizes ${ }^{[5]}$ by $1,3-\mathrm{H}$-shift (7), followed by ring closure to give the 1,2-dihydro-1,3-diphosphete $\mathbf{8}$. Nitrogen derivatives isoelectronic to $\mathbf{6}$ and $\mathbf{8}$ are known, a $\mathrm{N}$-silylated bis(imino)phosphorane ${ }^{[6]}$ and a 1,2-dihydro- $1,2,3 \lambda^{5}, 4 \lambda^{5}$-diazadiphosphete, ${ }^{[7]}$ respectively.

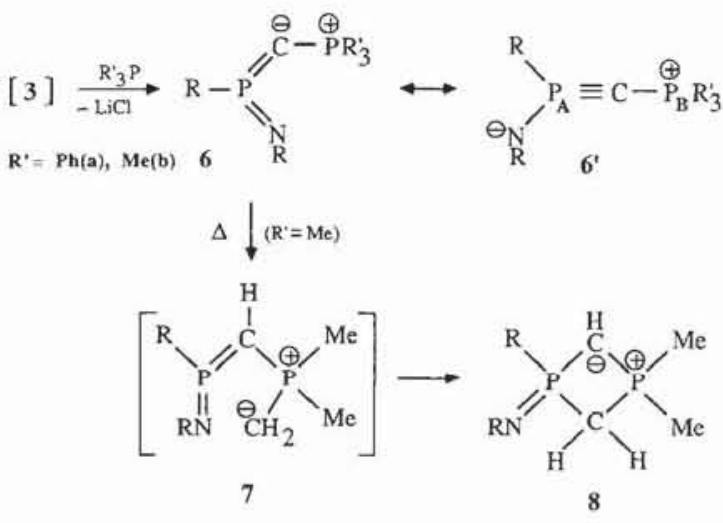

The compositions of compounds $\mathbf{2}, \mathbf{4}, \mathbf{5}, \mathbf{6} \mathrm{a}$, and $\mathbf{8}$ are confirmed by elemental analyses and mass spectra. Their constitution in solution is verified by NMR spectra and, in case of compounds 2 and 4 by X-ray structure analysis. ${ }^{[8]}$ In the lowfield region of the NMR spectrum the imino(methylene)phosphoranes $\mathbf{2 , 4}$, and $\mathbf{5}$ show the characteristic resonances for the $\mathrm{P}=\mathrm{C}$ structural unit ${ }^{[8 \mathrm{~b}]}\left(\delta\left({ }^{31} \mathrm{P}\right)=70.1\right.$ (2), 86.2 (4), $75.0(5)$; $\delta\left({ }^{13} \mathrm{C}\right)=99.9\left(J_{\mathrm{CP}}=245.9 \mathrm{~Hz}\right)(2), 93.7\left(J_{\mathrm{CP}}=119.8 \mathrm{~Hz}\right)(4)$, $\left.93.9\left(J_{\mathrm{CP}}=184.0 \mathrm{~Hz}\right)(5)\right)$. In the phosphoranes $\mathbf{6} \mathbf{a}, \mathbf{b}$ the signal (split by the phosphonio group) for the three-coordinate phosphorus atom is shifted drastically to higher field $(\delta=20.4$ (6a), $36.8(\mathbf{6 b})$ ); the observed shift lies in the expected range for bis(imino)phosphoranes. ${ }^{\left[9 \mathrm{c}, 1^{10]}\right.}$ The position of the signal of the phosphonio group and the value of ${ }^{2} J_{\mathrm{PP}}$ correspond with the values reported for carbodiphosphoranes ${ }^{[11]}(\delta=-12.4$, $\left.{ }^{2} J_{\mathrm{PP}}=111.8 \mathrm{~Hz}(\mathbf{6 a}) ; \delta=-21.0,{ }^{2} J_{\mathrm{PP}}=63.3 \mathrm{~Hz}(\mathbf{6} \mathbf{b})\right)$. The position of the signal for the two-coordinate carbon atom $(\delta=90.8(6 \mathbf{a}))$ at low field in comparison to carbodiphosphoranes, ${ }^{[12]}$ and the relatively large coupling constants ${ }^{1} J_{\mathrm{CP}}$ $\left(219.7 \mathrm{~Hz}\left[\mathrm{P}_{\mathrm{A}}\right], 162.1 \mathrm{~Hz}\left[\mathrm{P}_{\mathrm{B}}\right](\mathbf{6 a})\right)$ can be interpreted in terms of participation of the limiting dipolar structure $6^{\prime}$ and are also indicative of the formal relationship with alkylidinephosphoranes, ${ }^{[9 \mathrm{~d}]}$ especially the phosphonium salt $\left[\left(i \mathrm{Pr}_{2} \mathrm{~N}\right)_{2} \mathrm{P}=\mathrm{C}=\mathrm{PH}\left(i \mathrm{Pr}_{2} \mathrm{~N}\right)_{2}\right]^{+}\left[\mathrm{F}_{3} \mathrm{CSO}_{3}\right]^{-} \cdot{ }^{-13\}}$

The composition and constitution of $8 \mathrm{can}$ be deduced from the high-resolution mass spectrum (molecule peak) and from the results of NMR measurements. The four-membered ring structure is verified by the observation of resonance signals for one $\mathrm{CH}$ and one $\mathrm{CH}_{2}$ unit, in which each of the carbon atoms $(\mathrm{CH}$ : $\delta=41.7,{ }^{1} J_{\mathrm{CP}}=89,84 \mathrm{~Hz} ; \mathrm{CH}_{2}: \delta=40.3,{ }^{1} J_{\mathrm{CP}}=60,51 \mathrm{~Hz}$ ) shows direct coupling to each of the two phosphorus atoms. In contrast to the NMR data obtained for $6 \mathbf{a}$, the chemical shifts for the ylidic carbon atom and for the proton bonded to it, as 
well as the value of the ${ }^{2} J_{\mathrm{PP}}$ coupling constant $(25.8 \mathrm{~Hz})$, are quite typical. The unusual steric strain of the molecule hinders rotation of both aryl ligands, this gives rise to temperature-dependent coalescence phenomena in the ${ }^{1} \mathrm{H}$ and ${ }^{13} \mathrm{C}$ NMR spectra for the signals of the neighboring and non-neighboring substituents. Below temperatures of $-50{ }^{\circ} \mathrm{C}$ the rotation is completely "frozen" on the NMR timescale.

Figure 1 shows the structure of compound 4 in the crystal. As in all bis(ylene)phosphoranes that have been structurally investigated. the central phosphorus atom is in a trigonal-planar

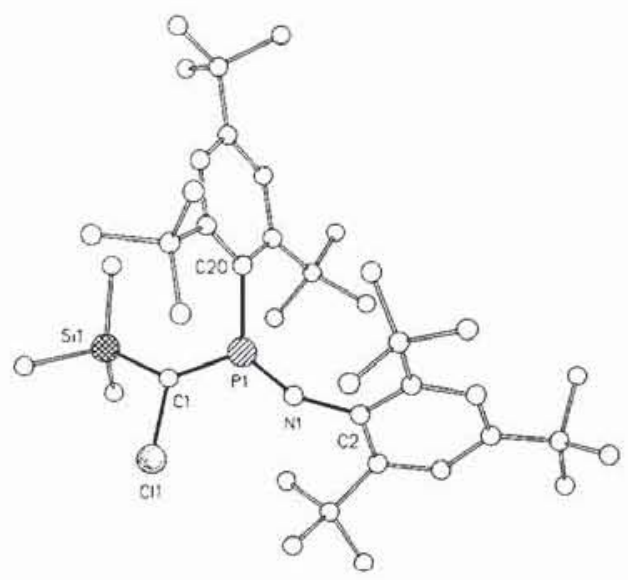

Fig. 1. Structure of imino(methylene)phosphorane 4 in the crystal. Selected bond lengths [pm] and angles [ ] (in parentheses the data for 2): $\mathrm{P} 1=\mathrm{C} 167.0(3)[165.5(5)]$, $\mathrm{P} 1-\mathrm{C}_{\text {ari }} 182.5(3)[181.1(6)], \mathrm{P} 1=\mathrm{N} 152.0(2)[152.3(3)] . \mathrm{C}_{\text {arry }}-\mathrm{P} 1-\mathrm{C} 108.1(1)[107.7(2)]$, $\mathrm{C}_{x+y}-\mathrm{P} 1-\mathrm{N} 128.1(1)[128.9(2)] . \mathrm{C}-\mathrm{P} 1-\mathrm{N}$ 122.6(1) [121.8(3)].

coordination environment $\left(\Sigma 358.8^{\circ}\right)$. The atoms $\mathrm{Cl} 1$ and Si1 are approximately coplanar with the N1-P1-C1 plane (the angle between the planes P1-C1-Cl1-Si1 and C20-P1-N1-C1 is $15^{\circ}$ ), whereas the $\mathrm{C} 2$ atom is positioned out-of-plane (dihedral angle C20-P1-N1-C2 -58 $\left.; \mathrm{C} 1-\mathrm{P} 1-\mathrm{N} 1-\mathrm{C} 2137^{\circ}\right)$. In contrast to those in $\mathbf{1}$, the two aryl substituents in $\mathbf{4}$ are $Z$-configurated and orthogonal. The sterically more demanding methylene substituent $\left(\mathrm{SiMe}_{3}\right)$ occupies the favored exo position. The $\mathrm{P} 1-\mathrm{N} 1$ $(150.0(2) \mathrm{pm})$ and $\mathrm{P} 1-\mathrm{C} 1$ distance $(167.0(3) \mathrm{pm})$, and the C1-P1-N1 $\left(122.6(1)^{\circ}\right)$ and C2-N1-P1 angles $\left(145.8(2)^{\circ}\right)$ correspond with typical structural features found for imino(methylene)phosphoranes. ${ }^{[9 \mathrm{~b}]}$ All important parameters for compound 2 deviate only slightly from those of 4 .

\section{Experimental Procedure}

2: To a solution of chloroform $(1.67 \mathrm{~g}, 14 \mathrm{mmol})$ in THF $(50 \mathrm{~mL})$ and ether $(10 \mathrm{~mL})$, an equimolar amount of $\mathrm{nBuLi}$ in $\mathrm{n}$-hexane was added at $-105^{\circ} \mathrm{C}$. After the mixture had been stirred for $1 \mathrm{~h}, 1(4.3 \mathrm{~g}, 8 \mathrm{mmol})$ in ether $(20 \mathrm{~mL})$ was added dropwise. After warming the solution to $25^{\circ} \mathrm{C}$ the volatile constituents were removed under vacuum and the remaining residue was taken up in hexane, and the insoluble material $(\mathrm{LiCl})$ was separated by filtration. Compound 2 crystallized from the concentrated filtrate at $-30^{\circ} \mathrm{C}$. Yield: $45 \% ; \mathrm{m} . \mathrm{p}, 174-176^{\circ} \mathrm{C} ; \mathrm{MS}(70 \mathrm{eV}) \mathrm{m} / \mathrm{c}$ $(\%): 617(12)\left[M^{+}\right] .57(100)\left[t \mathrm{Bu}^{+}\right]$.

4. 5: At -105 C. $n$ BuLi $(0.63 \mathrm{~mL}, 1.6 \mathrm{M}$ solution in $n$-hexane $)$ was added to a solution of $2(620 \mathrm{mg} .1 \mathrm{mmol})$ in $\mathrm{THF}(10 \mathrm{~mL})$ and $\mathrm{Et}_{2} \mathrm{O}(1 \mathrm{~mL})$. After the mixture had been stirred for $1 \mathrm{~h}, \mathrm{Me}_{3} \mathrm{SiCl}(200 \mathrm{mg} .1 .8 \mathrm{mmol}$ ) was added; the solution was then allowed to warm to room temperature. The volatile constituents were removed under vacuum, the residue was taken up in $n$-hexane, and the $\mathrm{LiCl}$ that had formed was filtered off. From the concentrated filtrate 4 crystallized at $-30^{\circ} \mathrm{C}$ as a pale yellow solid. Yield: $69 \%$; m.p. $175-177^{\circ} \mathrm{C}$. Compound 5 is obtained in a similar fashion in the absence of $\mathrm{Me}_{3} \mathrm{SiCl}$. Yield: $52 \%$. M.p. $148-150^{\circ} \mathrm{C}$.

4: $\mathrm{NMR}$ (without aryl) ' $\mathrm{H}\left(\mathrm{CDCl}_{3}\right): \delta=-0.19\left(\mathrm{~s}, \mathrm{SiMe}_{3}\right) ;{ }^{13} \mathrm{C}\left(\mathrm{CDCl}_{3}\right): \delta=93.7$ (d, $\left.J_{\mathrm{CP}}=119.8 \mathrm{~Hz}, \mathrm{P}=\mathrm{C}\right),-0.8\left(\mathrm{~d},{ }^{3} J_{\mathrm{CP}}=3.6 \mathrm{~Hz}, \mathrm{PCSi} C_{3}\right) ; \mathrm{MS}(70 \mathrm{eV}) m / e(\%)$ : $619(2)\left[M^{*}\right], 57(100)\left[t \mathrm{Bu}^{+}\right]$.
5: NMR (without aryl) ${ }^{1} \mathrm{H}\left(\mathrm{CDCl}_{3}\right): \delta=5.26$ (ddt. ${ }^{3} J_{\mathrm{HP}}=2.0,{ }^{3} J_{\mathrm{ImI}}=7.0$. $10.3 \mathrm{~Hz}, \quad$ PCCH), 3.92 ("q". $\left.{ }^{2} J_{\mathrm{HH}}={ }^{3} J_{\mathrm{HH}}=7.2 \mathrm{~Hz}\right), \quad 3.57$ (dd, ${ }^{2} J_{\mathrm{HP}}=$ $\left.32.4,{ }^{3} \mathrm{HH}_{\mathrm{HH}}=10.3 \mathrm{~Hz}, \mathrm{PCH}\right), 2.21\left(\mathrm{~m}, \mathrm{OCCH}_{2}\right) 1.95\left(\mathrm{~m}, \mathrm{OCCH}_{2}\right):{ }^{13} \mathrm{C}\left(\mathrm{CDCl}_{3}\right)$ $\delta=93.9$ (d, $\left.J_{C P}=184.0 \mathrm{~Hz}, P=C\right), 75.2\left(\mathrm{~d},{ }^{2} P_{C P}=1.8 \mathrm{~Hz}, \mathrm{PCCO}\right), 67.3$. $34.2,26.5\left(\mathrm{~s}, \mathrm{C}_{4} \mathrm{O}\right.$ framework); $\mathrm{MS}(70 \mathrm{eV}) \mathrm{m} / \mathrm{e}(\%): 619(<1)\left[\mathrm{M}^{+}\right] .100(100)$ $\left[\mathrm{BBu}^{+}\right]$.

6. 7: Reaction of $2(620 \mathrm{mg} .1 \mathrm{mmol})$ with $n \mathrm{BuLi}(0.63 \mathrm{~mL} .1 .6 \mathrm{M}$ in hexane at $-105^{\circ} \mathrm{C}$ yielded quantitatively ( ${ }^{3 i} \mathrm{P}$ NMR control) the stable phosphorane $6 \mathrm{a}$, which, following removal of $\mathrm{LiCl}$. was obtained as a pale yellow solid. In contrast, reactions with $\mathrm{PMe}_{3}$ yielded the unstable intermediate $6 \mathrm{~b}$. which isomerized to 8 during workup of the reaction solution. $6 \mathrm{a}$ : Yield: $83 \%$, m.p. $154^{\circ} \mathrm{C}$ (decomp.): MS (70 eV) m/e (\%): 809 (35) $\left[M^{+}\right], 752(100$ $\left[M^{+}-t \mathrm{Bu}^{+}\right] ; 8: \mathrm{MS}(70 \mathrm{eV}) m / e(\%): 623(0.4)\left[M^{+}\right], 566(100)\left[M^{+}-t \mathrm{Bu}^{+}\right]$ $608(3)\left[M^{+}-\mathrm{CH}_{3}\right]$

Received: November 26, 1993 Revised: January 21, 1994 [Z 6514 IE] German version: Angew. Chem. 1994, 106, 1037

[1] P. J. Stang in Methoden Org. Chem. (Houben-Weyl) 4th ed. 1952-, Bd. E. 19b. 1989. pp. 84-165: H. Yamamoto in Comprehensive Organic Synthesis, Vol. 2 (Eds.: I. Fleming. B. Trost), Pergamon, Oxford, 1992, p. 81

12] R. Appel, C. Casser, M. Immenkeppel, Tetrahedron Letl. 1985, 26, 3551-3554 R. Appel, M. Immenkeppel, Z. Anorg. Allg. Chem. 1987. 7-14: M. Yoshifuji. R. Niitsu, N. Inamoto, Chem. Lett. 1988, 1733-1734: S. J. Geode. F. Bickel haupt. Chem. Ber. 1991, 124, 2677-2684: M. Yoshifugi. H. Kawanami. Y Kawai, K. Toyota, M. Yasunami, T. Nitsu. N. Inamoto. Chem. Letl. 1992. 1053-1056.

[3] M. Lysek, Dissertation, Bielefeld, 1987.

[4] G. Köbrich, K. Flory, R. H. Fischer, Chem, Ber. 1966, 99. 1793-1804.

[5] For the formation of 8 , de- and reprotonation of 6 is also conceivable.

[6] A. V. Ruban. A. B. Drapailo, V. D. Romanenko, L. N. Markovskil. $\mathrm{Ch}$. Obshch. Khim. 1986, 56, 2791-2792.

[7] J. Böske, E. Niecke, B. Krebs, M. Läge, G. Henkel, Chem. Ber. 1992. I25. $2631-2634$.

[8] a) X-ray structure analysis for $2[4] \mathrm{C}_{37} \mathrm{H}_{58} \mathrm{Cl}_{2} \mathrm{NP}\left[\mathrm{C}_{40} \mathrm{H}_{6}-\mathrm{ClNPSi}-1 / 2\right.$ tolu ene]: orange [yellow] crystals, crystal dimensions $0.25 \times 0.40 \times 0.40[0.40 \times 0.50$ $\times 0.70] \mathrm{mm} ; M_{\mathrm{r}}=618.7[702.5$ with solvent $]$; space group $C 2 / c$ (no. 15) $\left[P 2_{1} / n\right]$. $a=36.605(4)[9.994(1)] . b=10.684(1)[26.039(2)], c=22.571(2)[17.034(2)] \AA$. $\beta=120.77(1)^{3}\left[90.19(1)^{\circ}\right], V=7.585(1)[4.433(1)] \mathrm{nm}^{3}, \mathrm{Z}=8[4] . \rho_{\text {calcd }}=1.08$ [1.05] $\mathrm{g} \mathrm{cm}^{-3}, \mu\left(\mathrm{Cu}_{\mathrm{K}_{\mathrm{z}}}\right)=2.10[1.55] \mathrm{mm}^{-1}: 5607$ [6581] symmetry-independent reflections $\left(2 \theta_{\max .}=120^{\circ}\left[120^{\circ}\right], T=293[193] \mathrm{K}\right)$, of which $3473[6158]$ reflections with $F>\mathrm{p} \sigma(F)(\mathrm{p}=3[4])$ were used for structure solution (direct methods) and refinement (368 [434] parameters), non-hydrogen atoms an isotropic, $\mathrm{H}$ atoms refined with a "riding" model: $R=0.067[0.062]\left(R_{\mathrm{w}}=\right.$ $0.068[0.071], w^{-1}=\sigma^{2}(F)=g F^{2}, g=0.0008[0.0001]$. Extinction correction (for 4 ) and empirical absorption correction (for 2 ) was applied by using the program DIFABS. In 2 a p-tert-buty! group is disordered (s.o.f. C31, C32. $\mathrm{C} 33=0.62(1))$. In 4 a toluene molecule is disordered over an inversion center. Further details of the crystal structure investigations may be obtained from the Fachinformationszentrum Karlsruhe, D-76344 Eggensteir-Leopoldshafen (FRG), on quoting the depository number CSD-58059. b) N. Walker, D. Stuart, Acta Crystallogr. Sect. A 1993, 39.158-166.

[9] a) Multiple Bonding and Low Coordination in Phosphorus Chemistry (Eds.: M Regitz, O. J. Scherer). Thieme, Stuttgart, 1990; b) H. Heydt in [9a], pp. 375 390 ; c) E. Niecke, D. Gudat in [9a], p. 392-403; d) G. Bertrand in [9a]. pp. $443-454$

[10] The endojendo bis(imino)phosphorane $\mathrm{R}-\mathrm{P}(=\mathrm{NR})=\mathrm{NSiMe}_{3} \quad(\mathrm{R}=2,4.6$ $\left.t \mathrm{Bu}_{3} \mathrm{C}_{6} \mathrm{H}_{2}\right)$, which is isoelectronic to 6 has a ${ }^{31} \mathrm{P}$ NMR shift of $\delta=66[6]$.

[11] S. O. Grimm in Phosphorus-31 NMR Spectroscopy in Stereochemical Analysis (Eds.: J. G. Verkade, L. D. Quin). VCH, Deerfield Beach, FL, 1987. pp. 645 664.

[12] H. Schmidbaur. O. Gasser. M. Sakhawat Hussain, Chem. Ber. 1977, 110, $3501-3507$.

[13] $\delta^{13} \mathrm{C}\left(99,{ }^{1} J_{\mathrm{CP}}=157.9\left(\mathrm{CP}_{\mathrm{A}}\right), 143.4\left(\mathrm{CP}_{\mathrm{B}}\right) \mathrm{Hz}\right) ; \delta^{31} \mathrm{P}\left(27.2\left(\mathrm{P}_{\mathrm{A}}\right), 3.1\left(\mathrm{P}_{\mathrm{R}}\right)\right.$ ${ }^{2} J_{p p}=120.8 \mathrm{~Hz}$ ). M. Soleilhavoup, A. Baceiredo. O. Treutler. R. Ahlrichs, M. Nieger, G. Bertrand. J. Am. Chem. Soc. 1992, 114. 10959-10961 